\title{
NATALIA LEBEDEVA'S PEDAGOGICAL AND CREATIVE WAY
}

УДК 37.032:78.071

DOI https://doi.org/10.32843/2663$6085 / 2021 / 33-2.8$

\section{Скоромний В.П.,}

народний артист України,

просресор кафедри

музичного мистецтва

ПВН3 «Київський університет культури»
Окреслюється необхідність розширення проблем, що розглядаються у педагогічному дискурсі. Підкреслено потребу розши рювати науковий інтерес у напрямі вивчення здобутків окремих персоналій, що дозволяє поглибити знання та окреслити нов сутнісні характеристики. Досліджується специфріка педагогічних і творчих принципів Наталії Лебедєвої. ї̈ педагогічна діяльність у Київській муніципальній академії музики імені Р.М. Глієра вплинула на розвиток українських провідних джазових виконавців.

Керуючи класом джазового ансамблю, Лебедєва сприяє фоормуванню навичок спільного узгодженого музикування. Основою методики Наталії виступає підтримка прагнення студентів до самовираження. Партнерство та підтримка є базисом, який сприяє зростанню джазових виконавців. Розвиток практичної зацікавленості студентів, підготовка до практики джазового виконавства $\epsilon$ основою для принципів, які реалізуються у викладацькій діяльності Лебедєвої. Потреба створення ансамблевого звучання у поєднанні з необхідністю розвивати навички джазової імпровізації $є$ провідним методичним принципом Лебедєвої як викладача.

Творчі напрацювання Лебедєвої як композитора реалізуються у напрямі фр'южн як простору для поєднання класики, джазу, фольклорних традицій різних народів, що промовляються за допомогою сучасної музичної лексики. Нерідко авторка звертається до класичних творів Й.С. Баха та Ф. Шопена, які постають по-новому у джазовому обрамленні, що притаманно для багатьох джазменів. Ії композиції відповідають провідним тенденціям, які поширені у світовій виконавській джазовій практиці. В інструментальних композиціях зустрічаються поліритмічні та поліметричні структури, виконання яких потребує чіткої кооперації між усіма учасниками ансамблю. Виконання джазових творів також вимагає взаємодії між учасниками прочесу, між джазменами та публікою, яка виступає основним адресатом.

Ключові слова: джаз, педагог, Наталія Лебедєва, методичні принципи, виконавство.
The need to expand the problems considered in pedagogical discourse is outlined. The scientific interest in the direction of studying the achievements of individuals is expanding, which allows deepening knowledge and outlining new essential characteristics. The peculiarity of pedagogical and creative principles of Natalia Lebedeva is studied. Her pedagogical activity at the R. Glier Kyiv municipal academy of music influenced the development of Ukrainian leading jazz performers. Leading a jazz ensemble class, Lebedeva promotes the formation of skills of joint coordinated music making.

The basis of Natalia's methodology is to support students' desire for self-expression. Partnership and support are the basis for the growth of jazz performers. The development of students' practical interest, preparation for the practice of jazz performance is the basis of the principles that are implemented in the teaching activities of Lebedeva. The need to create an ensemble sound in com bination with the need to develop the skills of jazz improvisation is the leading methodological principle of Lebedeva as a teacher. Lebedeva's creative works as a composer are realized in the direction of fusion, as a space of combination of classics, jazz, folk traditions of different peoples, which are pronounced with the help of modern musical vocabulary. The author often refers to the classical works of JS Bach and F. Chopin, which appear in a new way in the jazz frame, which is typical of many jazzmen. Her compositions correspond to the leading trends that are common in the world jazz practice. In instrumental compositions there are polyrhythmic and polymetric structures, the performance of which requires clear cooperation between all members of the ensemble. Similarly, the performance of jazz works requires interaction between the participants in the process, between jazzmen and the audience, which is the main addressee.

Key words: jazz, teacher, Natalia Lebedeva, methodical principles, performance.
Постановка проблеми в загальному вигляді. Українське джазове мистецтво активно розвивається упродовж останніх десятиліть. Його еволюціонування пов'язане 3 діяльністю музикантів, які задають високий рівень виконавської майстерності у цьому напрямі естрадного мистецтва. Серед українських джазменів виділяється постать Наталії Лебедєвої, яка є провідною виконавицею, педагогом, композитором та аранжувальником. Іїі діяльності, яка безпосередньо пов'язана з розвитком вітчизняного джазу, досі не було приділено уваги.
Аналіз останніх досліджень і публікацій. Питання дослідження педагогічної персоналії у дискурсі сучасної історико-педагогічної науки розкриваються у працях Г. Бєлан [1]. Розвиток джазового мистецтва, специоріка дихотомії «джаз та академічна музика» аналізуються у працях О. Войченко [2], О. Шпортько [3]. Методичні основи навчання джазової імпровізації $€$ предметом розвідок О. Павленко [5]. Особливості творчого шляху Н. Лебедєвої висвітлювалися у публіцистичних статтях Л. Даниленко [4] та А. Юдіна [6]. 
Виділення не вирішених раніше частин загальної проблеми. Творчі досягнення Наталії Лебедєвої розкривалися у низці публікацій, що мають публіцистичний характер. Висвітлення тих методичних принципів, які реалізуються на виконавській і педагогічній ниві, сприятимуть фрормуванню уявлення про її внесок у розвиток джазової освіти України.

Мета статті - дослідити особливості виконавської, композиторської та педагогічної діяльності української джазової піаністки Наталії Лебедєвої.

Виклад основного матеріалу. Сучасна педагогіка динамічно розвивається. Деякі автори, зокрема Г. Бєлан, наголошують на потребі розширення проблем у педагогічному дискурсі. Потрібно розширювати науковий інтерес у напрямі вивчення здобутків окремих персоналій, що дозволяє поглибити знання та окреслити нові сутнісні характеристики. «Вивчення, конструктивний аналіз педагогічної персоналії дають змогу не лише осмислити цілісну картину історико-педагогічного процесу в Україні, а й відкрити новий зміст, нові грані раніше досліджених наукових явищ і феноменів, розширити й поглибити ареал вітчизняної педагогічної думки у діахронічному вимірі» [1, с. 11]. Обравши цей ракурс, що базується на дослідженні здобутків окремих персоналій, розкриємо специфіку розвитку джазової освіти України на прикладі діяльності Наталії Лебедєвої.

Наталя Лебедєва є піаністкою, чия творча діяльність вплинула на розвиток провідних джазових виконавців. Ії̈ викладацький шлях у Київській муніципальній академії музики імені Р.М. Глієра триває вже більше 25 років, де завдяки її керівництву класом джазового ансамблю було виховано багато провідних вітчизняних виконавців. Вона почала цікавитися джазом ще на етапі, коли він не мав великої популярності та розповсюдженості в Україні. Формування її власної виконавської джазової манери відбувалося під впливом майстрів світового джазу: Біла Еванса, Хербі Хенкока, Джона Колтрейна, Чіка Коріа та Пета Метіні.

Творчий шлях Наталі Лебедєвої як професійної виконавиці-піаністки розпочався з 1995 року, коли вона створила тріо 3 Андрієм Арнаутовим (басгітара) та Аліком Фантаєвим (ударні). Тоді ж було записано перший диск, до якого увійшли авторські композиції Лебедєвої. Попри те, що Наталя чимало уваги приділяла виконавству у складі тріо, вона була учасницею й інших проєктів, здебільшого організованих ії колишніми студентами, а нині - провідними джазовими музикантами. Виконавиця сорормувала власний неповторний стиль, який має відкритий характер, полягає у значній експериментальності та широті образної палітри від франку до лірики.

Творча співпраця на уроках джазового ансамблю є запорукою для організації спільних проєктів. Зазначимо, що завдяки співпраці з Лебедєвою та її безпосередній підтримці змогло реалізувати свій творчий потенціал чимало виконавців. Причому основою методики Наталії $€$ звернення до студентів як до професіоналів, що рівні з викладачем у своєму прагненні до самовираження. Партнерство та підтримка $€$ базисом, на якому «виростають» молоді джазові таланти.

Робота на заняттях відбувається у руслі, що стимулює практичну зацікавленість студентів. Обирається музичний матеріал, який дозволяє ознайомити учасників ансамблю 3 провідними джазовими напрямами сьогодення. При спільній ансамблевій грі відбувається не лише введення молодих музикантів до сорери серйозного джазу, а й виявляються їхні можливості до мистецтва імпровізації, без якого не можливий джаз. О. Павленко визначає імпровізацію як «вид художньокреативної діяльності, під час якої творчий продукт створюється оригінальними музично-виразними засобами джазового мистецтва» [5, с. 92].

Жодний урок із джазового ансамблю у Наталі не відбувається без створення імпровізацій. Хоча $€$ й теоретичний курс, який ознайомлює студентів з основами джазової імпровізації, проте необхідні можливості практичного застосування навиків імпровізування. Розвиток майстерності ансамблевого виконавства, яке б включало створення повноцінних композицій і демонстрацію здатності імпровізувати кожним виконавцем, постає основою методичних принципів Лебедєвої як викладача.

Нерідко обираючи репертуар для студентів, джазова виконавиця пропонує «стандарти», які набувають незвичного прочитання, будучи представленими у мейнстрімних стильових напрямах. Проте якщо говорити про специоріку її власного творчого спрямування, то композиції Лебедєвої можна віднести до напряму ф'южн. Джазова музика має синтетичну природу, вбираючи елементи різних етнічних культур. О. Войченко зазначає про поліетнічність «джазової музики, що містить не одну національну або регіональну традицію, а являє собою міжкультурний сплав - «ф'южн», що свідчить про ії полістилістику» [2, с. 264]. Проте найвищим рівнем розвитку ідеї музичного синтезу у джазі є саме фр'южн як простір, де можливо поєднати класику, джаз, фрольклорні традиції різних народів, які промовляються за допомогою сучасної музичної лексики.

Чимало альбомів Н. Лебедєвої пов'язано 3 переосмисленням класичних творів Й.С. Баха, Ф. Шопена. Так, у її творчому доробку $є$ альбом "QUESTS", натхненний музикою Ф. Шопена. Його було записано у складі джазового секстету. Твори провідного барокового композитора увійшли до альбому "ВАCH IN JAZZ", де джазове тріо Лебедєвої виступило разом із дуетом скрипок "Тwo Violins". 
Подібний мікст джазових опусів та класики є одним із популярних трендів, представлених як у закордонних музикантів, так і у вітчизняних. «Звернення до класичних тем $є$ своєрідною поступкою та кроком у бік любителів академічної музики, які скоріше сприймуть оброблення Бахівської теми, аніж швидкий потік у напрямі бібоп, заснований на авторському музичному матеріалі. Цей напрям, тобто поява класики у джазі, яскраво виявляється у багатьох музикантів, вони випускають цілі альбоми на класичні теми» [3, с. 109].

Окрім опрацювання «хітів» академічного мистецтва, виконавицю цікавить і сучасна музика. Зокрема, нею був створений проєкт "COVER Z", який увібрав інструментальні версії пісень співачки Земфріри Рамазанової. Ця широта музичних уподобань якнайкраще демонструє спроможність джазового мистецтва стирати кордони між різними стильовими напрямами, виявляючи можливість перетворюватися у відповідному джазовому обрамленні.

Безперечно, що власна композиторська та виконавська діяльність Лебедєвої є наочним прикладом для розвитку молодим джазовим виконавцям. Сприймаючи її мистецькі принципи через споглядання та безпосередню участь у музичному дійстві, вони налаштовуються на створення якісного джазового контенту. В подальшому нерідко колишні студенти продовжують співпрацю 3 Н. Лебедєвою, яка підтримує усі креативні ініціативи молоді. Серед останніх проєктів Лебедєвої є співробітництво зі співачкою Лаурою Марті, знайомство з якою відбулося ще під час навчання останньої в КМАМ Глієра. Згодом співробітництво дійшло до рівня співтворчості. У спільному проєкті до авторської музики Наталії було додано англомовний текст, написаний Лаурою.

Результат є таким, що дозволяє демонструвати високий рівень українського джазу у світовому музичному просторі та часто презентується на українських концертних заходах. Також у співпраці з Лаурою і Христиною Марті вийшло три авторських диски: "Paints", "Medium Cool", "Tatransky Сај". Виконавиця чимало виступала на різних джазових фестивалях: Leopolis Jazz Fest, Art Jazz Cooperation, Jazz Bez, Koktebel Jazz Festival, Asu Jazz Fest, Jazznica, EU Jazz Express, Jazz Jamboree, Bielska Zadymka Jazowa та інших, де мала змогу співпрацювати та спілкуватися із провідними закордонними виконавцями.

Якщо говорити про структуру композицій, які створює джазова виконавиця, то вони є досить складними. В них наявні елементи сюїтності, а не куплетної чи строфрічної фрорми. Часто на фрон теми медитативного характеру може виникнути контрастний розділ, пов'язаний з етнічними елементами. Украй важливим для джазу є те, що він, як вказує Лебедєва, дуже активно реагує на зміни, які відбуваються у культурі, світі, мистецтві. Тому джаз модифрікується та вбирає елементи електронної музики, етнічної музики, академічної музики. В цьому є його сила та перспективність. Музичне мислення авторки орієнтоване на здобутки світової та американської джазової сцени й демонструє високий рівень майстерності.

Виконавська імпровізаційна манера Лебедєвої $є$ зразком для наслідування для молодих джазменів. Кожен, хто потрапляє на заняття ансамблем, має змогу не лише почути основні принципи її імпровізаційних патернів, а й перейняти їх. Ії̈ імпровізацію окреслюють так: «Імпровізації Наталії Лебедєвої зазвичай будуються як розвиток мелодійних ліній, часто через повторення і видозміну музичних фрраз, яке не відпускає увагу своїм поступовим накопиченням енергії, вихлюпується у фрінальних акордах» [6]. Також зазначимо, що в тих композиціях Лебедєвої, які є суто інструментальними, нерідко зустрічаються поліритмічні та поліметричні структури, що є досить складним для виконання й потребує чіткої кооперації між усіма учасниками ансамблю.

Одним із головних принципів виконавця, на думку Лебедєвої, є осягнення важливості бути відповідальним перед публікою, яка має розуміти виконавця, навіть не усвідомлюючи кожен елемент музичної композиції. Має здійснюватися контакт 3 аудиторією, яка б відчувала внутрішні інтенції музикантів. «На концерті, навіть граючи найрозумнішу і концептуальну музику, музикант грає для публіки. Ми повинні бути дуже щирі та відкриті внутрішньо, повинні донести людям свою любов до цієї музики і те задоволення, яке ми отримуємо, граючи цю музику» [4].

Н. Лебедєва зазначає, що музичне мистецтво $є$ таким, яке не можна сприймати суто раціонально. Воно повинно зачіпати на почуттєвому рівні. Обов'язково має бути взаємодія між учасниками музичного процесу. Причому єдиним шляхом привертання аудиторії до джазу, на думку піаністки, $€$ його сприйняття через живе виконання, яке не може бути нічим замінене. «Музика - така субстанція, яка сприймається на рівні відчуттів, а не на рівні інтелекту. Якщо немає вібрацій щодо озвученого поля, безглуздо пояснювати, що таке музика. Потрібно прийти на концерт і перш за все «підключитися» до енергетики. Подивитися, як руки, губи, очі музиканта живуть, як це все працює і відтворює. Піти на якийсь джазовий концерт, солянку, безкоштовний open air, джем-сейшн, просто потусуватися» [4].

Джазове мистецтво України має значний потенціал для розвитку, адже є чимало молоді та професійних музикантів, які вже досягли високого рівня майстерності. Головним завданням $€$ створення умов, за яких не буде відтоку творчого потенціалу та будуть надаватися можливості для подальшого еволюціонування. Саме завдяки роботі професіоналів, які відчувають відповідальність за свою 
творчість і педагогічну діяльність, можливе досягнення головної мети - створення за допомогою мистецтва умов для міжкультурного діалогу та єднання людства.

Висновки. Педагогічний вимір діяльності Наталі Лебедєвої полягає у зверненні уваги на ансамблеве джазове виконавство. Основний акцент припадає на виховання навичок імпровізування. У своїй творчій діяльності Лебедєва обирає мейнстрімні напрями джазу, зокрема ф'южн. Основою авторського підходу Наталії Лебедєвої є поєднання елементів різних шарів музичної культури: академічної музики, джаз та фольклор. Досить складна музична лексика її композицій відповідає провідним тенденціям, які поширені у світовій виконавській джазовій практиці. В інструментальних композиціях зустрічаються поліритмічні та поліметричні структури, виконання яких потребує чіткої кооперації між усіма учасниками ансамблю. Так само й виконання джазових творів вимагає взаємодії між учасниками процесу, між джазменами та публікою, яка є основним адресатом.

Подальші перспективи досліджень можливі у напрямі розвідок специсріки творчих та педаго- гічних напрацювань інших представників джазової сцени України.

\section{БІБЛІОГРАФІЧНИЙ СПИСОК:}

1. Бєлан Г.В. До проблеми дослідження педагогічної персоналії у дискурсі сучасної історико-педагогічної науки. Педагогічні науки, 2012. Вип. 1(61). C. 11-15.

2. Войченко О.М. Джазове мистецтво у просторі художньої практики XVIII - XXI ст. Культура України, 2013. Випуск 40. С. 257-266.

3. Войченко О.М., Шпортько О.В. Дихотомія «джаз та академічна музика»: минуле та сьогодення. Імідж сучасного педагога, 2020. № 3(192). С. 107-110.

4. Даниленко Л. Наталя Лебедєва: «Якщо джазмен - не імпровізатор, це не джазмен». URL: https://mind.ua/style/20172919-natalya-lebedevayakshcho-dzhazmen-ne-improvizator-ce-ne-dzhazmen (дата звернення: 29.01.2021).

5. Павленко О.М. Методичні основи навчання джазової імпровізації майбутнього вчителя музики. Актуальні питання мистецької педагогіки, 2013. Вип. 2. С. 91-95.

6. Юдин А. Трио Натальи Лебедевой и Лаура Марти. URL: https://32jazz.club/tryo-nataly-lebedevojy-laura-marty/ (дата звернення: 29.01.2021). 